\title{
Bridging the Gap between Evidence and Practice: A Systematic Review-When Is the Best Time to Clamp the Infant's Umbilical Cord in Term Low-Risk Women?
}

\author{
Jane Houston, Lilla Dillon, Ashley Duvall, Margaret McGuire \\ University of Florida, Gainesville, USA \\ Email: houstonj@ufl.edu
}

Received 26 August 2014; revised 24 September 2014; accepted 8 October 2014

Copyright (C) 2014 by authors and Scientific Research Publishing Inc.

This work is licensed under the Creative Commons Attribution International License (CC BY). http://creativecommons.org/licenses/by/4.0/

\section{(c) (i) Open Access}

\begin{abstract}
Historically, in midwifery and obstetric care, the umbilical cord was not usually clamped until all pulsation of the cord had ceased. This is now referred to as delayed cord clamping or DCC (not clamping umbilical cord before two minutes of life). During the last one hundred years with changes in the ways women give birth, especially the shift toward hospital based birth in the Western world, it became commonplace for the cord to be clamped within 20 - 30 seconds of birth (immediate cord clamping or ICC). Authors have postulated various reasons for this shift in timing of umbilical cord clamping to include a possible decreased risk of postpartum hemorrhage, the need for resuscitation of the newborn and sampling of cord blood for stem cells and cord blood analysis. Recent evidence suggests that newborns (particularly in low-resourced settings) would benefit greatly from a policy of DCC with decreased risks of childhood anemia, subsequent sequelae and the need for supplementation. This systematic review examined recent literature from the last eight years using commonly used academic search engines with associated keywords. The results were carefully collated into a table of findings and outcomes.
\end{abstract}

\section{Keywords}

Umbilical Cord, Timing of Umbilical Cord Clamping, Delayed Cord Clamping, Immediate Cord Clamping, Early Cord Clamping, Late Cord Clamping, Postpartum Hemorrhage

\section{Introduction}

Historically the umbilical cord was not severed until all pulsation had stopped and the neonate had begun

How to cite this paper: Houston, J., Dillon, L., Duvall, A. and McGuire, M. (2014) Bridging the Gap between Evidence and Practice: A Systematic Review-When Is the Best Time to Clamp the Infant's Umbilical Cord in Term Low-Risk Women? Open Journal of Nursing, 4, 730-736. http://dx.doi.org/10.4236/ojn.2014.411078 
breathing spontaneously; this is referenced by various authors from 200 to 2000 years ago (Soranus [1], Darwin [2]). In recent times it appears that often the umbilical cord is clamped and cut within 30 seconds of birth to allow for resuscitation maneuvers as well as decisions related to collection of cord stem cells and umbilical cord blood for blood gas analysis; despite mounting evidence that there may be health benefits to the baby (Ceriani Cernadas et al. [3], Vain et al. [4]). It was also once thought that immediate or early clamping of the umbilical cord (ICC/ECC, within 30 seconds of birth) prevented postpartum hemorrhage. A recent opinion from the Royal College of Obstetricians and Gynecologists notes that "immediate cord clamping became routine practice without rigorous evaluation" (Duley et al. [5]).

However controversy still surrounds this issue. Concerns regarding delayed cord clamping (DCC) may include jaundice and polycythemia of the neonate. Although asymptomatic polycythemia is more common with delayed cord clamping, it does not result in significant differences in the bilirubin level within the first three days of life (Coggins and Mercer [6]).

This review aims to examine current practice and present evidence demonstrating the beneficial short and long-term effects that delayed or late cord clamping (DCC/LCC) may have for the infant. These include higher mean hemoglobin levels, iron stores as well as reduced prevalence of iron deficiency anemia (Gyorkos et al. [7]. Milking the umbilical cord five times at birth is also associated with a decreased risk for iron-deficiency anemia (Erickson-Owens et al. [8])

This evidence is also extremely important for low-resourced countries. Because of the positive effect DCC can have on iron stores, fewer infants could potentially avoid suffer iron-deficiency anemia (Weckert and Hancock [9]). The additional volume that the baby receives during DCC can be up to $80-100 \mathrm{ml}$ of blood (Yao et al. [10]). A recent Cochrane review documented evidence in favor of delaying cord clamping for at least two minutes to improve long-term outcomes for infants (McDonald et al. [11]).

Practitioners involved in birth including nurse-midwives, physicians and PAs should be aware of the latest research and recommendations and consider advocating for protocol updates and adjusting their practice accordingly (Tonse [12])

\section{Objective}

To systematically review recent and classic literature pertaining to timing of umbilical cord clamping and to present evidence from recent studies related to timing of cord clamping.

\section{Methods}

We each independently searched Pubmed/MEDLINE, CINHAL and the Cochrane Library for relevant articles from the past ten years (one classic paper from 1969 was also cited) using the following search terms "Umbilical cord" "timing of umbilical cord clamping" "delayed cord clamping"; "immediate cord clamping" "early cord clamping" "late cord clamping" "postpartum hemorrhage".

The reviewed articles were all originally published in English. They were retrieved using text pattern matching to search for the commonly used words and phrases noted above. The studies reviewed here include randomized trials, systematic literature reviews as well as observational studies and practice recommendations. Browsing the reference lists of these papers (both the primary studies and reviews) that have been identified by the database searches identified further studies of interest. We included 24 relevant studies of which 21 are summarized in Table 1 and a diagram of the review process is illustrated via use of a flow chart in Table 2 . The recent studies reviewed are from 2006-2014 inclusive.

\subsection{Effects on Hematocrit, Hemoglobin, and Blood Volume}

A classic study examined the effects of DCC on 111 subjects [10]. The authors noted that placental blood is rapidly transferred into the neonate following birth and delays of 60 - $180 \mathrm{~s}$ can have significant effects on the volumes of blood transferred to the baby at birth. Jahazi et al. [13] note that when the umbilical cord is clamped immediately, as much as $30 \%$ of the neonate's blood can remain in the placenta. For the first $20-25$ seconds of life, blood continues to flow in the umbilical arteries from the newborn to the placenta. The placental residual volume recorded was almost $40 \%$ lower in LCC group in comparison to the ICC group, and the estimated neonatal blood volume was $7.1 \%$ higher than that of ECC. 
Table 1. Analysis of findings of 21 reviewed articles.

\begin{tabular}{|c|c|c|c|c|}
\hline Author & Type & Population & Outcome & Other \\
\hline $\begin{array}{l}\text { Andersson } \\
\text { et al. }(2012) \\
{[21]}\end{array}$ & $\begin{array}{l}\text { Secondary analysis of } \\
\text { DCC }(>3 \text { min) and ECC } \\
(<10 \text { s) on PPH }\end{array}$ & $\begin{array}{l}\mathrm{N}=382 \\
\text { Exp }=193 \\
\text { Control = } 189\end{array}$ & $\begin{array}{l}\text { No significant difference } \\
\text { between ECC and DCC } \\
\text { in regards to PPH }\end{array}$ & $\begin{array}{l}\text { Infants'cord gas analysis no } \\
\text { significant differences demonstrated. }\end{array}$ \\
\hline $\begin{array}{l}\text { Andersson } \\
\text { et al. (2013) } \\
\text { [15] }\end{array}$ & $\begin{array}{l}\text { RCT of full-term } \\
\text { infants to have cord } \\
\text { clamped at }>3 \text { minutes } \\
\text { (DCC) or }<10 \text { seconds } \\
\text { (ECC)-effects on } \\
\text { neurodevelopment and } \\
\text { infection at four months } \\
\text { of age }\end{array}$ & $\begin{array}{l}\mathrm{N}=400 \\
\mathrm{DCC}-168 \\
\text { ECC-166 }\end{array}$ & $\begin{array}{l}\text { DCC did not appear to } \\
\text { affect overall } \\
\text { neurodevelopment or } \\
\text { symptoms of infection } \\
\text { at } 4 \text { months. }\end{array}$ & $\begin{array}{l}\text { May be an impact on specific } \\
\text { neurodevelopmental domains. } \\
\text { DCC is a safe alternative for } \\
\text { infants born at term. }\end{array}$ \\
\hline $\begin{array}{l}\text { Bhatt, } \\
\text { et al. (2013) } \\
\text { [17] }\end{array}$ & $\begin{array}{l}\text { RCT animal study of } \\
\text { effects of DCC on CV } \\
\text { function of preterm } \\
\text { lambs }\end{array}$ & $\begin{array}{l}\mathrm{N}=12 \\
\text { Exp }=6 \\
\text { Control = } 6\end{array}$ & $\begin{array}{l}\text { Delaying cord clamping } \\
\text { until the onset of ventilation } \\
\text { improves CV stability in } \\
\text { preterm lambs. }\end{array}$ & $\begin{array}{l}\text { The benefits of DCC may not result } \\
\text { from increased blood volume, but } \\
\text { from a more stable CV transition to } \\
\text { pulmonary respiration. }\end{array}$ \\
\hline $\begin{array}{l}\text { Blouin } \\
\text { et al. (2011) } \\
\text { [23] }\end{array}$ & $\begin{array}{l}\text { Pre/post study design } \\
\text { of a two component } \\
\text { intervention on mean } \\
\text { time of cord clamping }\end{array}$ & $\begin{array}{l}\mathrm{N}=234 \\
\text { 112-preinetervention } \\
\text { 112-postintervention }\end{array}$ & $\begin{array}{l}\text { All deliveries were observed } \\
\text { after } 3 \text { day training of "best } \\
\text { practices" related to cord } \\
\text { clamping and a hospital } \\
\text { directive. Following } \\
\text { interventions mean times to } \\
\text { clamping increased to } 168.9 \\
\text { seconds from } 56.8 \text { seconds. }\end{array}$ & $\begin{array}{l}\text { It is possible to change hospital } \\
\text { practice from ECC to DCC with } \\
\text { a training program and hospital } \\
\text { directive. May help to combat } \\
\text { infant anemia in low resource } \\
\text { settings. }\end{array}$ \\
\hline $\begin{array}{l}\text { Ceriani } \\
\text { Cernadas, } \\
\text { et al. (2006) [3] }\end{array}$ & $\begin{array}{l}\text { RCT of effects of ECC } \\
(<15 \text { s) and DCC ( } 1 \\
\text { and } 3 \text { min) on venous } \\
\text { hematocrit levels }\end{array}$ & $\begin{array}{l}\mathrm{N}=276 \\
\mathrm{ECC}=93 \\
\mathrm{DCC} 1 \mathrm{~min}=91 \\
\mathrm{DCC} 3 \mathrm{~min}=92\end{array}$ & $\begin{array}{l}\text { DCC resulted in higher } \\
\text { hematocrit values and fewer } \\
\text { incidences of anemia }\end{array}$ & $\begin{array}{l}\text { No significant differences } \\
\text { between the groups in regards to } \\
\text { bilirubin levels or polycythemia. }\end{array}$ \\
\hline $\begin{array}{l}\text { Chaparro } \\
\text { et al. }(2006) \\
\text { [22] }\end{array}$ & $\begin{array}{l}\text { RCT of ECC }(<20 \mathrm{~s}) \\
\text { and DCC }(>90 \mathrm{~s}) \text { on } \\
\text { infant iron status }\end{array}$ & $\begin{array}{l}\mathrm{N}=358 \\
\text { Exp }=171 \\
\text { Control = } 187\end{array}$ & $\begin{array}{l}\text { Iron status at } 6 \text { months of } \\
\text { age was significantly } \\
\text { higher in the DCC group }\end{array}$ & $\begin{array}{l}\text { No significant differences between } \\
\text { groups in regards to incidence of } \\
\text { clinical jaundice or polycythemia. } \\
\text { DCC had greater effect on iron } \\
\text { status of infants at greater risk for } \\
\text { iron deficiency. }\end{array}$ \\
\hline $\begin{array}{l}\text { Coggins, } \\
\text { M., \& Mercer, } \\
\text { J. (2009) [6] }\end{array}$ & $\begin{array}{l}\text { Literature review, } \\
\text { recommendations } \\
\text { for practice } \\
\text { (AWHONN) }\end{array}$ & & $\begin{array}{l}\text { DCC improves iron stores } \\
\text { and lessens risk of developing } \\
\text { anemia in term infants. } \\
\text { DCC in preterm infants is } \\
\text { associated with better } \\
\text { respiratory function and } \\
\text { improved cerebral oxygenation. }\end{array}$ & $\begin{array}{l}\text { DCC not associated with clinical } \\
\text { jaundice, polycythemia, or PPH. } \\
\text { A delay in cord clamping until } \\
\text { pulsation stops is recommended. }\end{array}$ \\
\hline $\begin{array}{l}\text { Committee } \\
\text { on Obstetric } \\
\text { Practice (2012) } \\
\text { [20] }\end{array}$ & $\begin{array}{l}\text { Literature review } \\
\text { describing timing } \\
\text { of umbilical cord } \\
\text { clamping and the } \\
\text { associated benefits } \\
\text { of DCC (ACOG) }\end{array}$ & & $\begin{array}{l}\text { There is insufficient } \\
\text { evidence to support or } \\
\text { refute the benefits of DCC }\end{array}$ & $\begin{array}{l}\text { Benefits of DCC may include } \\
\text { increased blood volume, reduced } \\
\text { need for blood transfusion, } \\
\text { decreased incidence of intracranial } \\
\text { hemorrhage in preterm infants, and } \\
\text { decreased frequency of iron } \\
\text { deficiency in term infants. Benefits } \\
\text { must outweigh risks. Current } \\
\text { evidence does support DCC in } \\
\text { preterm infants. DCC infants may } \\
\text { be at increased risk for phototherapy. }\end{array}$ \\
\hline $\begin{array}{l}\text { Duley } \\
\text { et al. (2009) [5] }\end{array}$ & $\begin{array}{l}\text { Royal College of } \\
\text { Obstetricians and } \\
\text { Gynecologists } \\
\text { (RCOG) Opinion paper }\end{array}$ & & $\begin{array}{l}\text { Evidence suggests that ECC } \\
\text { lowers neonatal hemoglobin } \\
\text { and lowers iron stores. } \\
\text { Impact on term and preterm } \\
\text { infants remain unclear. }\end{array}$ & $\begin{array}{l}\text { More substantive RCTs are } \\
\text { required comparing outcomes } \\
\text { and long term follow up for } \\
\text { mother and baby. }\end{array}$ \\
\hline $\begin{array}{l}\text { Erickson-Owens } \\
\text { et al. }(2012) \text { [8] }\end{array}$ & $\begin{array}{l}\text { RCT of ICC }(<10 \mathrm{~s}) \\
\text { and UCM (milked } \mathrm{x} \\
5 \text { by the obstetrical } \\
\text { provider) in women } \\
\text { delivering by } \\
\text { cesarean section }\end{array}$ & $\begin{array}{l}\mathrm{N}=24 \\
\text { Exp }=12 \\
\text { Control = } 12\end{array}$ & $\begin{array}{l}\text { UCM results in higher Hct } \\
\text { levels at } 36 \text { to } 48 \text { h of age } \\
\text { when compared to ICCU } \\
\text { mbilical cord milking can be } \\
\text { a viable alternative to DCC }\end{array}$ & $\begin{array}{l}\text { No significant differences between } \\
\text { two groups in regards to } \\
\text { symptomatic polycythemia, } \\
\text { incidence of clinical jaundice, or } \\
\text { hyperbilirubinemia. }\end{array}$ \\
\hline
\end{tabular}




\section{Continued}

$\begin{array}{lll}\begin{array}{l}\text { Gyorkos } \\ \text { et al. (2012) }\end{array} & \text { Cohort study } & \mathrm{N}=224 \\ \text { [7] } & \text { Pre/Post test } & \text { matched pairs } \\ \text { model } & \text { (women and infants) }\end{array}$

A change in hospital policy toward DCC is effective in improving hemoglobin levels and anemia status of 8-month-old infants.

Timed clamping of cord in large tertiary care center in

Hutton

et al. (2013) Observational [24] study

$\mathrm{N}=98$ women

Canada. Over half (56.5\%)

of infants cords clamped

within 15 seconds

Neonatal hematocrit at $2 \mathrm{~h}$

of life and $18 \mathrm{~h}$ did not

significantly differ between

the two groups

Lack of agreement on definition of ICC and DCC.

Examined articles on term and preterm infants and role of $\mathrm{PPH}$.

Male infants with DCC had

Psychomotor Developmental Index (PDI) scores an average of 18 points higher compared with infants with ICC. DCC was also associated with protection against IVH and sepsis among male neonates.

Literature review Describes the Scheans neonatal benefits (2013) [14] of DCC (1 - 3 min or until cord stops pulsating)

Tonse Literature review of (2013) current evidence and recommendations

Tonse Opinion Comment;

(2014) The Lancet

$\begin{array}{ll}\text { Vain } & \text { Randomized Trial } \\ \text { et al. (2014) } & \begin{array}{l}\text { examining effect of } \\ \text { gravity of placental } \\ \text { [4] }\end{array} \\ \text { transfusion volumes }\end{array}$

Weckert

Literature Review of [9] Literature Review
current evidence

Yao Case control study-

et al. (1969) rate of placental

[10]
$\mathrm{N}=72$

VLBW infants

Review of

Literature

Review of literature

$\mathrm{N}=546$ newborn

term infants

$\mathrm{E}=194$

$\mathrm{C}=197$

111 full term newborns
DCC results in improved iron stores

Follow guidelines from professional bodies, recommend waiting at least 30 seconds to clamp cord

ICC is an intervention; obstetricians and midwives should wait two minutes before clamping cord

Position of the newborn before cord clamping does not appear to affect volume of placental transfusion

Babies with DCC had increased packed cell volumes, additional iron stores, hemoglobin levels, and ferritin levels up to 6 months old.

Within one minute of birth $50 \%$ of placental volume infused to newborn. Additional $20-35 \mathrm{ml} / \mathrm{kg}$ transfused if cord is not clamped for 3 minutes.
No difference in hematological status between the pre- and post-intervention groups at 4 months of age perhaps because only after 4 - 6 months of life that the distribution of iron content approaches stability.

There was a change in policy guidelines at the center to delay cord clamping. Study should be repeated to determine compliance.

In the LCC group, PRBV was lower and ENBV was higher, with no significant difference for polycythemia. Authors used differing definitions of cord clamp timing from standard.

DCC may be beneficial in areas where iron deficiency is prevalent.

No increased risk of PPH.

Authors suggest follow up of four years.

Asymptomatic polycythemia after birth was more common with DCC, but did not result in significant differences in bilirubin level.

Need more information regarding position of baby at birth, especially in Cesarean birth.

More research needs to be done in this area.

Mothers should be allowed to hold their babies immediately after birth Improve bonding Decrease iron deficiency No adverse events reported.

Cost effective Non-interventionist Non-harmful.

Holding the newborn $40 \mathrm{~cm}$ below the placenta- transfusion completed in 30 seconds. Transfusion takes longer if infant held higher, but is still completed.

Abbreviations: DCC = delayed cord clamping; ECC = early cord clamping; ENBV = estimated neonatal blood volume; $\mathrm{E}=$ experimental; $\mathrm{C}=\mathrm{Control}$; ICC = immediate cord clamping; LCC = late cord clamping; PPH = post partum hemorrhage; PRBV = placental residual blood volume; RCT = randomized controlled trial; UCM = umbilical cord milking; CV = cardiovascular; VLBW = Very low birth weight 
Table 2. Flow diagram representing review process of systematic review.

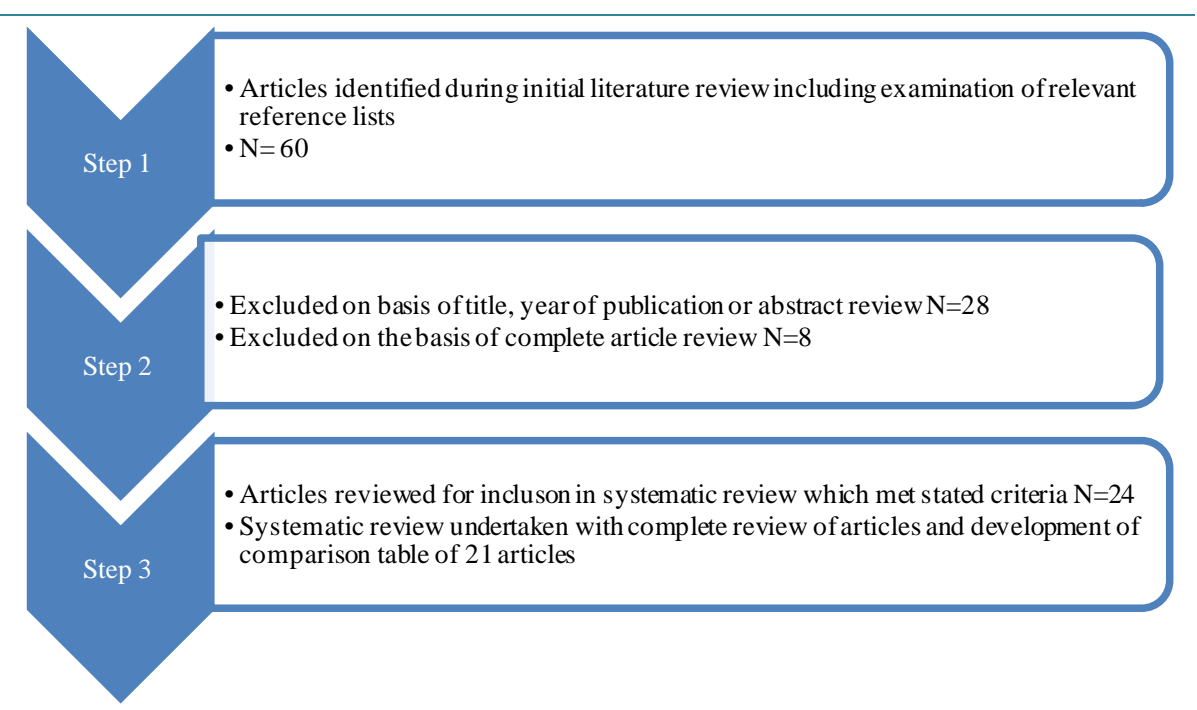

Systematic review of subject completed July 2014

Delaying cord clamping improves blood volume in the newborn, better oxygenating the baby as well as providing cardiovascular stability. The major lasting benefit, however, of delayed cord clamping is the improvement in iron stores. Iron is essential for brain function and development, and plays a major role in assisting the myelination of the cells in the central nervous system. Iron deficiency is associated with several cognitive deficits, such as altered affective responding and impaired motor development. In addition, several neurobehavioral effects, like altered temperament and abnormal neurologic reflexes have been associated with neonatal iron deficiency (Scheans et al. [14], Andersson et al. [15]). The Mercer et al. meta-analysisnoted that male infants with DCC scored an average of 18 points higher on the Psychomotor Developmental Index than infants with ICC. The improved iron stores associated with DCC also contribute to higher levels of hemoglobin and hematocrit for the newborns, lessening the risk of developing anemia [16].

This is a relevant concern because 26\% of European children are iron deficient (Andersson et al. [15]), and babies who experience DCC have $45 \%$ - 50\% higher levels of ferritin, the protein that binds to iron. "DCC can provide one to three months of iron storage, with protection from anemia and iron deficiency for up to six months." (Scheans et al. [14]).

\subsection{Considerations for Cesarean and Preterm Deliveries}

There has been relatively little research conducted on the effects of delayed cord clamping (DCC) in premature infants and those delivered by cesarean section, but the literature that is available on these subjects suggests that the benefits to these neonates are no different than those conferred to term and vaginally delivered neonates. There is also no observable increase in adverse outcomes and moreover, Bhatt et al. [17] suggest that the benefits of DCC may actually be greater in preterm infants than term infants.

Erickson-Owens et al. [8] compared hematocrit levels of infants delivered by cesarean section whose cord was clamped immediately to those whose cord was milked for 5 seconds before clamping. While delayed cord clamping is possible with cesarean sections (Smith, Plaat, \& Fisk [18]), cord milking is more convenient and seems to produce similar results. The infants whose cord was milked had significantly higher hematocrit values than those whose cord was clamped immediately. ICC also seemed to increase the risk of anemia. There was no increased risk for adverse outcomes associated with milking of the cord.

Bhatt et al. [17] in a small study of lambsfound that delaying cord clamping until the onset of ventilation in preterm lambs provided a gentler and stable hemodynamic transition than immediately clamping the cord before commencing ventilation. The author posited that this more stable transition might actually be the greatest benefit of DCC, rather than the increased blood volume. Traditional thought has stated that preterm infants needing resuscitation are the least likely candidates for DCC because of the urgent need for ventilation. However, this 
study found that not only are DCC and immediate ventilation not mutually exclusive, but DCC may actually enhance the benefits of ventilation. Resuscitation efforts then should be carried out while the umbilical cord is patent to receive the benefits of DCC.

The main reason stated in the literature for the introduction of ICC was to decrease the theoretical risk of increased maternal postpartum hemorrhage. According to the following review studies Duley et al. [5], Kohn [19], and Committee on Obstetric Practice [20] this theory has never actually been verified. In a large randomized study, Andersson et al. [21] noted no significant differences in postpartum hemorrhage groups of mothers whether the cord was cut and clamped early or late.

\subsection{Inconsistencies}

The research has shown several inconsistencies when reflecting upon the maternal and neonatal effects of DCC One major inconsistency is that of the optimal position of the infant after delivery in order to receive the abundance of nutrient-rich placental blood. Some of the studies suggested that the infant be held below the level of placenta, while others had the infant placed above or at the level of the placental until they clamped the cord. (Mercer et al. [16] suggest that the protocol at birth require the infant to be held approximately 10 to 15 inches below the placenta when the delaying of the cord clamping took place.) However this is discounted in a recent randomized trial by Vain et al. [4] who suggest that the immediate position of the baby after birth does not affect the volume of placental transfusion.

Another inconsistency is that of whether or not infants with DCC are at an increased risk for jaundice, and thus requiring phototherapy. McDonald et al. [11] reported an increased risk for jaundice needing phototherapy with infants with DCC from an unpublished study. However, this is inconsistent with the findings of all of the other studies included in this review. Coggins and Mercer [6] actually address these findings, but conclude them to be inconclusive due to the fact that the author's findings were based mostly on an unpublished doctoral thesis that only included one trial. This trial was done in the 1990s, and therefore had different criteria for initiating phototherapy than criteria used today. The final and most significant inconsistency would have to be that of the timing and terminology for early/immediate cord clamping vs delayed/late cord clamping. This literature review has determined from the available evidence that ECC/ICC would be defined asclamping of the umbilical cord less than 20 seconds following birth of the infant, whereas DCC/LCC would be greater than 30 seconds and/or until the cord stops pulsating.

\section{Conclusions}

The discussion regarding optimal timing of umbilical cord clamping in obstetric settings has continued over a number of years. The current preference for ICC appears based on provider preference and concerns for immediate resuscitation. More strong evidence is appearing that demonstrates the neonate benefits from the placental transfusion occurring with DCC and there are short and long term benefits including increased iron stores which can last for up to two years according to Chaparro et al. [22].

Risks to the mother or neonate of instituting a DCC protocol appear small. In low-resourced countries DCC appears to contribute to neonatal health and lowers the risk of anemia.

Health care providers including nurse-midwives, nurse-practitioners and PAs need to become informed of this issue and develop a consensus with obstetricians and neonatologists that will allow for placental transfusion.

There is a risk of bias inherent in any systematic review due to the differing nature, quality and analysis of studies presented. More research with larger randomized trials may finally and conclusively answer the posited question.

Perhaps we can all pay attention to Erasmus Darwin speaking to us from 1801 when he wrote, "Another thing very injurious to the child is tying and cutting of the navel string too soon; which should always be left till the child has not only repeatedly breathed but till all pulsation in the cord ceases. As otherwise the child is much weaker than it ought to be, a portion of the blood being left in the placenta which ought to be in the child.” [2].

\section{References}

[1] Temkin, O. (1956) Soranus’ Gynecology. Johns Hopkins Press, Baltimore.

[2] Darwin, E. (1801) Zoonomia. 302. http://www.gutenberg.org/files/15707/15707-h/15707-h.htm

[3] Ceriani Cernadas, J.M., Carroli, G., Pellegrini, L., Otaño, L., Ferreira, M., Ricci, C., Casas, O., Giordano, J. and Lar- 
dizábal, J. (2006) The Effect of Timing of Cord Clamping on Neonatal Venous Hematocrit Values and Clinical Outcome at Term: A Randomized, Controlled Trial. Pediatrics, 117, e779-e786. http://dx.doi.org/10.1542/peds.2005-1156

[4] Vain, N.E., Satragno, D.S., Gorenstein, A.N., Gordillo, J.E., Berazategui, J.P., Alda, M.G. and Rudent, L.M. (2014) Effect of Gravity on Volume of Placental Transfusion: A Multicenter, Randomized, Non-Inferiority Trial. The Lancet, 384, 235-240. http://dx.doi.org/10.1016/S0140-6736(14)60197-5

[5] Duley, L.M.M., Weeks, A.D. and Hey, E.N. (2013) Clamping of the Umbilical Cord and Placental Transfusion (Scientific Impact Paper 14). http://www.rcog.org.uk/clamping-umbilical-cord-and-placental-transfusion

[6] Coggins, M. and Mercer, J. (2009) Delayed Cord Clamping: Advantages for Infants. Nursing for Women's Health, 13, 133-139. http://dx.doi.org/10.1111/j.1751-486X.2009.01404.X

[7] Gyorkos, T.W., Maheu-Girous, M., Blouin, B., Creed-Kanashiro, H., Casapia, M., Aguilar, E., Silva, H., Joseph, S. and Penny, M.E. (2012) A Hospital Policy Change toward Delayed Cord Clamping Is Effective in Improving Hemoglobin Levels of Anemic Status of 8-Month-Old Peruvian Infants. Journal of Tropical Pediatrics, 58, 435-440. http://dx.doi.org/10.1093/tropej/fms012

[8] Erickson-Owens, D.A., Mercer, J.S. and Oh, W. (2012) Umbilical Cord Milking in Term Infants Delivered by Cesarean Section: A Randomized Controlled Trial. Journal of Perinatology, 32, 580-584. http://dx.doi.org/10.1038/jp.2011.159

[9] Weckert, R. and Hancock, H. (2008) The Importance of Delayed Cord Clamping for Aboriginal Babies: A LifeEnhancing Advantage. Women and Birth, 21, 1-5. http://dx.doi.org/10.1016/j.wombi.2008.09.004

[10] Yao, A., Moinian, M. and Lind, J. (1969) Distribution of Blood between the Infant and Placenta after Birth. The Lancet, 1, 871-873. http://dx.doi.org/10.1016/S0140-6736(69)92328-9

[11] McDonald, S.J., Middleton, P., Dowswell, T. and Morris, P.S. (2013) Effect of Timing of Umbilical Cord Clamping on Term Infant on Maternal and Neonatal Outcomes (Review). The Cochrane Collaboration, 7, CD004074.

[12] Raju, T.N.K. (2013) The Timing of Umbilical Cord Clamping after Birth for Optimizing Placental Transfusion. Current Opinions in Pediatrics, 25, 180-187. http://dx.doi.org/10.1097/MOP.0b013e32835d2a9e

[13] Jahazi, A., Kordi, M., Mirbehbahani, N.B. and Mazloom, S.R. (2008) The Effect of Early and Late Umbilical Cord Clamping on Neonatal Hematocrit. Journal of Perinatology, 28, 523-525. http://dx.doi.org/10.1038/jp.2008.55

[14] Scheans, P. (2013) Delayed Cord Clamping: A Collaborative Practice to Improve Outcomes. Neonatal Network: The Journal of Neonatal Nursing, 32, 369-373. http://dx.doi.org/10.1891/0730-0832.32.5.369

[15] Andersson, O., Domellöf, M., Andersson, D. and Hellström-Westas, L. (2013) Effects of Delayed Cord-Clamping on Neurodevelopment and Infection at Four Months of Age: A Randomised Trial. Acta Paediatrica, 102, 525-531. http://dx.doi.org/10.1111/apa.12168

[16] Mercer, J.S., Vohr, B.R., Erickson-Owens, D.A., Padbury, J.F. and Oh, W. (2010) Seven-Month Developmental Outcomes of Very Low Birth Weight Infants Enrolled in a Randomized Controlled Trial of Delayed versus Immediate Cord Clamping. Journal of Perinatology, 30, 11-16. http://dx.doi.org/10.1038/jp.2009.170

[17] Bhatt, S., Alison, B.J., Wallace, E.M., Crossley, K.J., Gill, A., Kluckow, M., tePas, A.B., Morley, C.J., Polglase, G.R. and Hooper, S.B. (2013) Delaying Cord Clamping until the Onset of Ventilation Improves Cardiovascular Function at Birth in Preterm Lambs. The Journal of Physiology, 591, 2113-2126.

[18] Smith, J., Plaat, F. and Fisk, N. (2008) The Natural Caesarean: A Woman-Centred Technique. BJOG: An International Journal of Obstetrics \& Gynaecology, 115, 1037-1042. http://dx.doi.org/10.1111/j.1471-0528.2008.01777.x

[19] Kohn, A. (2013) Time to Delay: A Literature Review of Delayed Cord Clamping. http://www.omicsgroup.org/journals/time-to-delay-a-literature-review-of-delayed-cord-clamping-2167-0897.1000119. php?aid=15780

[20] Committee on Obstetric Practice (2012) Timing of Umbilical Cord Clamping after Birth. Committee Opinion, 120, 1522-1526.

[21] Andersson, O., Hellström-Wesras, L., Andersson, D., Clausen, J. and Domellöf, M. (2012) Effects of Delayed Compared with Early Umbilical Cord Clamping on Maternal Postpartum Hemorrhage and Cord Blood Gas Sampling: A Randomized Trial. Acta Obstetricia et Gynecologica Scandinavica, 92, 567-574. http://dx.doi.org/10.1111/j.1600-0412.2012.01530.x

[22] Chaparro, C.M., Neufeld, L.M., Alavez, G.T., Cedillo, R.E. and Dewey, K.G. (2006) Effect of Timing of Umbilical Cord Clamping on Iron Status in Mexican Infants: A Randomised Controlled Trial. The Lancet, 376, 1248-1253.

[23] Blouin, B., Penny, M., Casapia, M., Eder, A., Hermann, S., Joseph, S., Creed-Kanashiro, M., Maheu-Giroux, M. and Gyorkos, T.W. (2011) Effect of a Two-Component Intervention to Change Hospital Practice from Early to Delayed Umbilical Cord Clamping in the Peruvian Amazon. Revista Panamericana de Salud Pública, 29, 322-328.

[24] Hutton, E.K., Stoll, K. and Taha, N. (2012) An Observational Study of Umbilical Cord Clamping Practices of Maternity Care Providers in a Tertiary Care Center. Birth, 40, 39-45. http://dx.doi.org/10.1111/birt.12027 
Scientific Research Publishing (SCIRP) is one of the largest Open Access journal publishers. It is currently publishing more than 200 open access, online, peer-reviewed journals covering a wide range of academic disciplines. SCIRP serves the worldwide academic communities and contributes to the progress and application of science with its publication.

Other selected journals from SCIRP are listed as below. Submit your manuscript to us via either submit@scirp.org or Online Submission Portal.
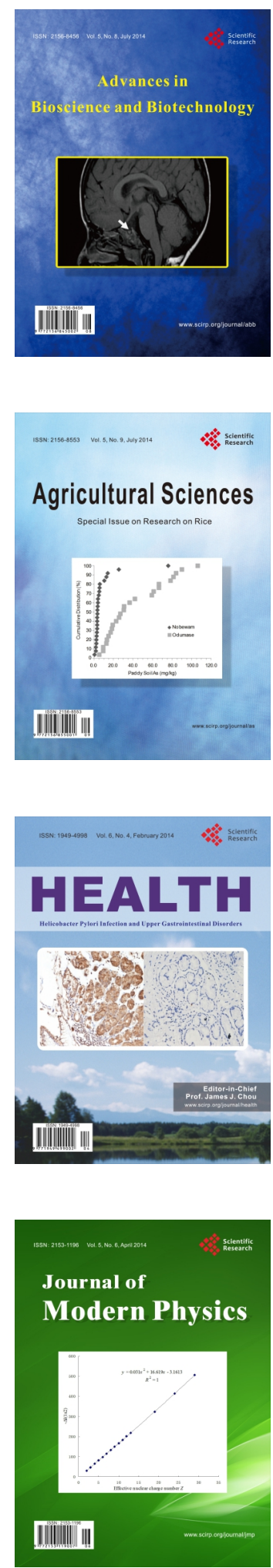
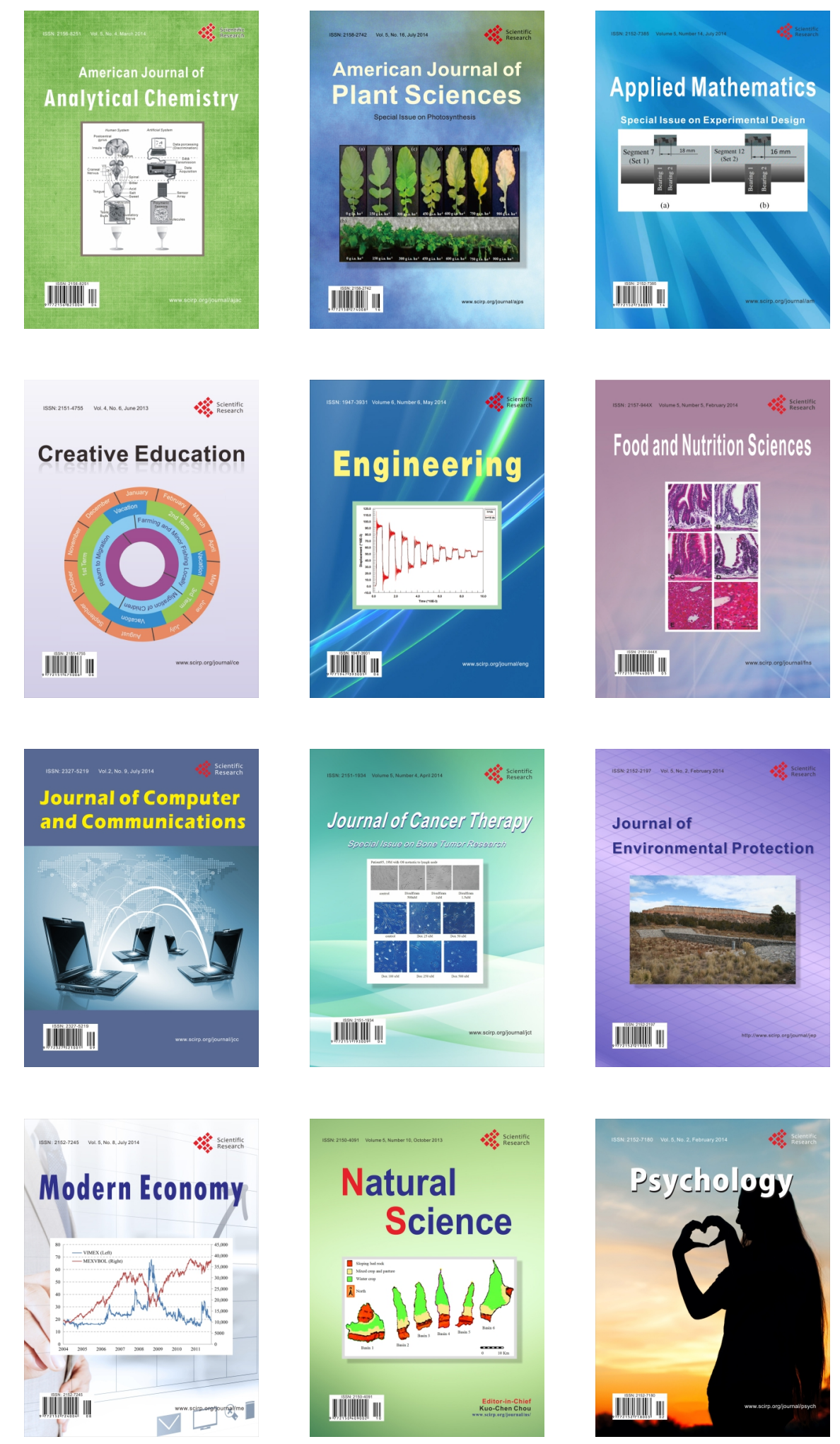